映画やアニメのキャラクターのフィギュアを好んで収集する人

は、かなりの数に上ると思われます。堂々と自分が「オタク」

だと公言する人もいれば、こっそりと部屋に数え切れないほど

のフィギュアを大切に陳列している人もいることでしょう。

しかし、多くのフィギュアが長持ちするプラスチック製だと
はいっても、新しいままの状態を半永久的に保てるわけではあ

りません。プラスチック作品を展示している博物館でも、近年、

展示品の劣化が始まっているようです。劣化を防ぐにはどのよ

うな対策をとればいいのか、読んでみましょう。

NEWS news@nature.com

語数 : 677 words 分野 : 高分子化学

Published online: 25 May 2007 | doi:10.1038/news070521-12

\title{
Plastics for posterity
}

How do you prevent valuable collectors' items from degrading?

http://www.nature.com/news/2007/070521/full/070521-12.html

Katharine Sanderson

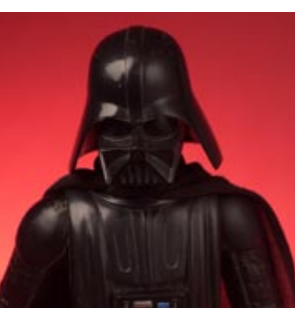

1. Many environmentalists would tell you that plastics, such as those that litter our oceans and landscapes, last for ever. But ask the collectors and museum curators who have gathered at London's Victoria and Albert Museum this week, and they will say the opposite.

2. They have met to discuss ways to prevent damage to culturally important plastic objects such as museum pieces and collectibles - created to last for ever, but doomed to degrade if not properly cared for.

3. Compared with paintings and sculptures, plastics have a short cultural history. But some plastics are now more than a century old, and preservation of some ageing items is becoming a headache. "You can't prevent degradation; you can only slow down the process," says Yvonne Shashoua from the National Museum of Denmark, Copenhagen.

4. Polyvinyl chloride, or PVC, is one of the big problems. "It is one of the plastics used the most in society," Shashoua says. Plastic figurines from cult movies such as Star Wars can attract whopping price tags if sold in pristine condition, but the Force isn't strong enough to keep the plastic from inevitable degradation.

\section{Black to white}

5. The trouble arises from the plasticizing additives used to prevent the PVC from turning out brittle. These plasticizers generally belong to a class of chemicals called phthalate esters and are only attached physically, rather than chemically, to the PVC polymer chain. Over time, this weak attachment breaks down and the plasticizers leak out to the surface of the material.

6. If the phthalate esters are exposed to an acidic environment - such as that present in many packaging materials - they form crystals of phthalic acid. And eventually that pristinely cared-for Darth Vader doll will end up with these crystals growing out of his famously fearsome black helmet, which rather ruins the effect. "Culturally, the figurines look a lot different if they've got a white head," says Shashoua. Not surprisingly, this reduces their value both commercially and culturally.

7. The best way to prevent such objects from deteriorating is to store them in a household freezer, Shashoua advises.

\section{Role for charcoal}

8. Other common plastics include cellulose acetate and cellulose nitrate. The artist Naum Gabo made several cellulose acetate sculptures, renowned glass artist René Lalique worked with cellulose nitrate in the 1920s, and early plastic dolls were made from cellulose nitrate. Both of these plastics degrade via an unstoppable chain reaction, which is initiated by light. "When I found out I immediately had the windows in the plastics gallery masked out," says Susan Mossman, plastics curator at the Science Museum in London.

9. Mossman is investigating the extent to which adsorbent materials placed with plastic exhibits 
affect degradation. Charcoal cloth, for example, has a huge surface area and can take up gases given out during the degradation process - including nitric acid or acetic acid, depending on the polymer. These by-products can themselves catalyse the polymer-breaking reaction in a process called autocatalysis.

10. The gases are easy to detect, says Amy Anderson from the National Trust's Museum of Childhood in Sudbury, UK. "You can smell a great waft of acids as you open the exhibiting case," she says.

11. Removing the emitted by-products from the system can therefore halt autocatalysis. Mossman also suggests that the main mechanism by which charcoal cloth slows the plastic's degradation is by removing oxygen from the system. Others say that

\section{Science key words}

4. Polyvinyl chloride : ポリ塩化ビニル (PVC)

一般的なプラスチックの一種で、塩化ビニル樹脂ともいう。塩化ビニ ル $\mathrm{CH}_{2}=\mathrm{CHCl}$ を付加重合させて合成され、柔らかくするための可塑 剤（下記参照）と劣化を防ぐ安定剤を加えて利用される。熱を加える と軟化する性質（熱可塑性）がある。プラスチック消しゴムやレジ袋 などの日用品から建築材料に至るまで、幅広い用途に使用されてい る。しかし近年では、焼却処理に伴うダイオキシンの発生源の 1 つと みられているため、製品への使用を控えるメーカーが増えている。

5. plasticizing additives : 可塑剤

同じ段落の plasticizersも同じ意味。PVCなどの熱可塑性合成樹脂に 添加して、柔軟性や対候性を改良する薬品類。

5. phthalate esters : フタル酸エステル

後述のフタル酸のエステル化合物の総称。PVCに使用される可塑剤と して利用されているが、環境ホルモンへの関心が高まる中、食品中な どに溶け出すことで人体に与える影響も取り沙汰されるようになっ た。また、フタル酸エステルの一部には、シックハウス症候群の原因 物質の 1 つ考えられているものもある。

\section{Words and phrases}

タイトル posterity :「後世」「子孫」

リード. degrading : 「劣化すること」

3.のdegradationは名詞形。7.のdeterioratingも同じ意味。

litter :「散らかす」「污す」

collectibles : 「収集品」

doomed to : $\ulcorner$ となる運命にある」

figurines : 「小さな像」

whopping : 「とてつもなく大きい」

バーガーキング社のWhopper（ワッパー）は、「とてつもなく大きい（ハ ンバーガー)」という意味が込められている。

4. in pristine condition : 「新品同様の」

pristineはもともと「原始の」「元の状態の」という意味だったが、「新 品同様の」「未使用の」という意味でも使われるようになった。

4. the Force : 「フォース」 the charcoal is more likely to be simply absorbing anything that is given off - including the acids.

12. One thing is clear: the problem of preserving plastics objects is not easy to solve, and the responsibility to maintain these preservation steps will fall to curators, says Mossman. "It requires good housekeeping," she says.

13. Shashoua agrees that plastics conservation is not set to get any easier, even with developments in new manufacturing processes. "Plastics made today are still made to last a particular length of time. We'll see the same problem when those plastics are old enough," she says. In the meantime, it might be worth renewing the insurance on your irreplaceable original Darth Vader before he starts to lose both his menace and his value.

5. polymer chain : 高分子鎖

複数の単量体が結合して鎖状になることによってできた高分子化合物のこと。

6. phthalic acid : フタル酸

化学式 $\mathrm{C}_{6} \mathrm{H}_{4}(\mathrm{COOH})_{2}$ で表されるベンゼンジカルボン酸。3つの異性 体がある。

8. cellulose acetate : 酢酸セルロース

セルロースの酢酸エステル。丈夫で、柔軟性、遅燃性、耐久性のある 熱可塑性物質。磁気テープやアセテートレーヨン、食品包装フィルム などに用いられる。耐薬品性、耐熱性、耐燃焼性にすぐれており、ま た、天然のセルロースを原料とした、人体や環境にやさしい樹脂とし て近年注目されている。

8. cellulose nitrate : 硝酸セルロース (ニトロ・セルロース)

セルロースを硝酸と硫酸の混合物で処理して作られる硝酸エステルの 総称。白色で、着火すると激しく燃える。ラッカー塗料や火薬、セル ロイドなどに用いられる。

9. catalyse : 触媒作用を及ぼす

触媒作用 (catalysis) とは、特定の物質がそれ自身は消耗されるこ となく、特定の化学反応を促進させる現象のこと。catalyseはその動 詞形。9.の autocatalysisは「自己触媒反応」「自触媒現象」のこと。

映画『スター・ウォーズ』に登場するジェダイの力の源泉。

inevitable : 「不可避の」「避けられない」

brittle : 「もろい」

white head : 「白にきび」

renowned : 「有名な」「著名な」

chain reaction : 「連鎖反応」

initiated : 「開始される」

adsorbent materials : 「吸着剤」

Charcoal cloth : 「炭布」

by-products : 「副産物」

a great waft of : $\ulcorner\sim$ 強い香り」

halt : 「中止する」「止める」

housekeeping : 「手入れ」

set to : 「(今後 $) 〜$ (といった状態 $)$ になる（ことに決まっている）」

menace : 「脅威」 
Published online: 25 May 2007 | doi:10.1038/news070521-12

\section{プラスチック作品を後世に残す}

どうすれば貴重なコレクターズアイテムの劣化を防げるだろうか。

http://www. nature.com/news/2007/070521/full/070521-12.html

キャサリン・サンダーソン

1. 多くの環境保護論者は、地球の海や景観を污しているプラス チックは、その姿を永久にとどめることになるというだろう。 けれども、今週ビクトリア・アルバート博物館（英国ロンドン） に集まったコレクターや博物館学芸員に質問すれば、これとは 反対の答えが返ってくるだろう。

2.この会議の目的は、博物館の所蔵品や収集品になるような文 化的に重要なプラスチック作品の損傷を防ぐ方法を議論するこ とにあった。これらの作品は、その姿を永久にとどめるべき ものとして制作されたが、適切な手入れをしないと劣化する 運命にあるのだ。

3. 絵画や彫刻と比べれば、プラスチックの文化史は短い。それで も、なかには1世紀以上の年月を経ているプラスチック作品も あり、年代物の作品の保存は頭の痛い問題になってきている。 「劣化を防ぐことはできません。遅らせることしかできないの です」ここう語るのは、デンマーク国立博物館（コペンハーゲン） のYvonne Shashouaである。

4. ポリ塩化ビニル (PVC) は大きな問題の1つである。「これ は、世間で最もよく使われているプラスチックの一種です」と Shashouaはいう。『スター・ウォーズ』のようなカルト・ムービー の登場人物をかたどったプラスチック製のフィギュアは、コン ディションがよければとんでもない高值で取り引きされるが、 強大なる「フォース」をもってしても、プラスチックの宿命で ある劣化から逃れることはできない。

\section{黒いヘルメットが白くなる}

5. 劣化の原因は、PVCの脆化を防ぐために用いられる各種の可 塑剤にある。こうした可塑剤は、一般にはフタル酸エステルに 分類される化学物質であり、PVCの高分子鎖と化学的に結合 することなく、物理的にのみ結合している。そのため、時間 が経つと、この弱い結合が壊れてきて、材料の表面に可塑剤 が漏れ出してくる。

6. 多くの梱包材の内部は酸性になっている。フタル酸エステルが こうした酸性環境に置かれると、フタル酸の結晶が析出する。 だから、ダースベイダーのフィギュアを手つかずのまま大切に 保管していても、いつかはあの有名な恐ろしい黒へルメットに フタル酸の結晶が出てきて、その印象を台無しにしてしまうの だ。「文化的にいうと、フィギュアに白にきびができると、感 じが大きく変わってしまうのです」とShashouaはいう。当 然のことながら、これによってフィギュアの価值は商業的にも 文化的にも低下する。

7. プラスチック製フィギュアの劣化を防ぐには家庭用冷凍庫で保管 するのがいちばんだ、というのがShashouaのアドバイスである。

\section{炭が果たす役割}

8. このほかに頻繁に用いられるプラスチックとしては、酢酸セル ロースと硝酸セルロースがある。芸術家ナウム・ガボは、酢酸 セルロース製の彫像をいくつか作った。ガラス工芸家として名 高いルネ・ラリックは、1920年代に硝酸セルロースで作品を 制作している。初期のプラスチック人形も、硝酸セルロースで 作られていた。どちらの素材も光によって始まり、止めるこ とのできない連鎖反応によって劣化する。「これを知ったとき、 私はすぐにプラスチック製品の展示室の空を覆いました」。こ う語るのは、科学博物館 (英国ロンドン) のプラスチック担当 学芸員のSusan Mossmanである。

9. Mossmanは、プラスチック製の展示品のそばに吸着剤を置い た場合に劣化のようすがどの程度変わってくるかを調べてい る。例えば、炭布は表面積が非常に大きく、プラスチックの劣 化の過程で放出されるガス (高分子の種類に応じて硝酸や酢酸 を含んでいる)を吸収することができる。このような副産物は、 それ自体が高分子分解反応を触媒する。これを自己触媒過程 という。

10. ナショナルトラスト子ども博物館（英国サドバリー）のAmy Andersonは、「ガスの存在はすぐにわかります。展示ケース を開くと、強い酸のにおいがするのです」という。

11. したがって、系から放出される副産物を除去すれば、自己触 媒反応を止められることになる。これに対してMossmanは、 炭布を置くことでプラスチックの劣化が遅くなるのは、系から 酸素が除去されることが大きいのではないかと提案している。 また、炭布は酸を含めて系から発せられる物質を片っぱしか ら吸収している可能性が高いとする意見もある。

12.「1つはっきりしているのは、プラスチック製品の保存に関す る問題の解決は容易でなく、こうした保存作業の励行は学芸員 の責任だということです。十分な手入れが必要なのです」と Mossmanは話す。

13. たとえ新たな製造法が開発されても、プラスチックの保存が簡 単になることはないだろうという点では、Shashouaも同じ 考えだ。「今日製造されているプラスチックも、耐久性には限 界があります。このようなプラスチックも、一定の年月を経れ ば、同じ問題が起こるのです」と彼女はいう。そういうわけで、 二度と手に入らないダースベイダーのオリジナルフィギュアを もっている人は、その威嚇的な風貌と価值が損なわれないう ちに保険契約を更新しておくといいかもしれない。 